\title{
Analytical methods for mercury analysis in coal and coal combustion
}

\section{by-products}

M. Antonia López-Antón, Mercedes Díaz-Somoano, Raquel Ochoa-González, M. Rosa Martínez-Tarazona*

Instituto Nacional del Carbón, INCAR (CSIC) C/ Francisco Pintado Fe, 26, 33011, Oviedo Spain

*Corresponding author

Phone: +34 985118988

Fax: +34985297662

e-mail: rmtarazona@incar.csic.es 


\begin{abstract}
This review deals with the analysis of mercury present in different types of solid, liquid and gaseous samples involved in the coal combustion process, focusing on the specific characteristics of each type of sample and the problems typically associated with these products. The main aim of the paper is to describe the methods that, at the current stage of development, are preferable in each case (i.e. the most frequently used in most laboratories and the standard methods). The advantages and disadvantages of each method are discussed with reference to the quality of the results and the uncertainties involved in the evaluation of mercury behaviour during coal combustion processes.
\end{abstract}

Keywords: Mercury, mercury analysis, mercury speciation, coal-fired power plants 


\section{Introduction}

Coal combustion is the main source of anthropogenic mercury emitted into the environment (UNEP, 2008). In Europe, mercury emissions from stationary combustion facilities represent $53 \%$ of the total amount of anthropogenic mercury in the air, whereas in North America they account for 43\% (Pirrone et al., 2010). The most recent estimates suggest that fossil fuel combustion produces $45 \%$ of the total mercury emitted world-wide from human activity (Pacyna et al., 2010). In light of these data and because: 1) the emission limits of mercury from coal burning power plants have not been universally defined; 2) measures to implement these limits are still under consideration; 3) the role of gas cleaning systems for $\mathrm{NOx}$, particulates and $\mathrm{SO}_{2}$ emissions in mercury emissions is still unknown; and 4) research into the development of systems for mercury capture is ongoing (UNEP, 2010a and 2010b), accurate replicable quantification of mercury present in the products involved in coal combustion is of great importance. Accuracy and precision in the analysis of a trace element as toxic as mercury are always essential, but in the case of the main anthropogenic source of this element, are crucial. To record mercury emissions and to develop methods for reducing them it is necessary to determine and identify mercury and its compounds in solid, liquid and gaseous products. Moreover, accurate and precise mercury analyses are the key to obtaining reliable information on emissions and on mass balances. The present review, therefore, discusses those methods that, at the current level of development, are generally preferred by laboratories which work with coal and coal combustion byproducts (CCBs), with reference to the quality of the results and the effect that analytical uncertainty has upon the evaluation of contamination. 


\section{1.-Mercury analysis: general considerations}

As is the case with analytical problems, to obtain reliable data on mercury content it is necessary to follow the appropriate sampling procedure and sample pretreatment process, to select the appropriate method of measurement, and to validate the results. During these operations, contamination and random loss of the element through volatilization, adsorption, diffusion etc., must be prevented. In the case of mercury, each and every one of these operations is critical and needs to be strictly controlled, because some mercury species are extremely volatile and can easily be adsorbed on and diffuse through the walls of containers and equipment employed.

Before describing how to analyze mercury, it is necessary to review some general features of the mercury compounds. Atmospheric mercury is commonly grouped into three predominant species: elemental mercury $\left(\mathrm{Hg}^{0}\right)$, which is the dominant species in the atmosphere; oxidized mercury $\left(\mathrm{Hg}^{\mathrm{II}}\right)$, which is the most reactive; and particulate mercury $\left(\mathrm{Hg}_{\mathrm{p}}\right)$. In general, oxidized mercury $\left(\mathrm{Hg}^{\mathrm{II}}\right)$ is the predominant form of mercury incorporated in soils (Schuster, 1991). $\mathrm{Hg}^{\mathrm{II}}$ may be reduced to elemental mercury $\left(\mathrm{Hg}^{0}\right)$ or it may become involved in methylation-demethylation cycles, acquiring a methyl group and resulting in methyl mercury $(\mathrm{MeHg})$, which is an especially toxic species (Ayira et al., 2009). Coal combustion and gasification is a source of $\mathrm{Hg}^{0}, \mathrm{Hg}^{\mathrm{II}}$ and $\mathrm{Hg}_{\mathrm{p}}$. $\mathrm{MeHg}$ is the end product of biochemical reactions, but as it is not present in coal and combustion by-products it is outside the scope of this paper. In the coal combustion process mercury compounds present in the feed materials and by-products are mainly inorganic species which are in solid, liquid, or gas phase. To analyze them, the preparation phase needs to be strictly controlled, because the volatilization of mercury from solid and liquid samples may occur. It may also be necessary to stabilize liquid 
samples and solutions obtained from solids in order to prevent their adsorption and diffusion through the containers. It is also important to bear in mind the ability of mercury to amalgamate with metals, and also to be cognizant of the problems arising from memory effects and interferences within the equipment.

\section{1.- Volatilization from solid samples during the preparation for analysis}

Mercury and its compounds are extremely volatile species. They may be lost during sampling, storage, preparation or analysis, even if the samples are subjected to relatively low temperatures. To our knowledge, no studies have been carried out on mercury evaporation at room temperature from coal. However, some research has been conducted on the possible evaporation of mercury from solid CCBs, including fly ashes and gypsum produced in flue gas desulphurization (FGD) units. These studies were mainly aimed at determining the loss of mercury when CCBs are processed for different industrial applications. For instance, Rubel et al. (2006) found that mercury was thermally stable up to $300{ }^{\circ} \mathrm{C}$ in a series of ash samples. However, studies carried out using modified versions of a laboratory test, especially designed for this evaluation and performed over different periods of time (Hassett et al., 2002; Hassett et al., 2004, Heebink and Hassett, 2004 Heebink and Hasset 2005), showed that mercury may be released from the FGD derived gypsum samples studied at temperatures between 150 and $180^{\circ} \mathrm{C}$. These studies also assessed the release of mercury in vapour form at longterm ambient and near-ambient temperatures from six $\mathrm{CCB}$ samples, with mercury contents ranging from 0.112 to $0.736 \mu \mathrm{g} \mathrm{g}^{-1}$. Although their results were found to be inconclusive because they varied depending on the experimental conditions, extremely low emissions of mercury from ash samples were observed. The average amount released from all these ashes was of the order of pg of mercury, and there was no clear 
evidence that the rate of mercury emitted was related to the total mercury concentration. What is remarkable is that in one series of tests (Heebink and Hassett, 2004) one of the ash samples appears to have absorbed mercury from the environment instead of losing it. The release of mercury from disposed or utilized CCBs requires additional study.

\section{2.-Stability of the liquid samples; adsorption and diffusion through the containers}

Loss of mercury from diluted solutions depends on a number of factors and that in a relatively short space of time may amount to more than $90 \%$ of all mercury within the sample (Lo and Wail, 1975). Two points must be taken into consideration. One is the possible loss of mercury during storage, and the other the possibility that the solution may be contaminated by adsorption of mercury from the walls of the container or the surrounding atmosphere. The stability of mercury solutions depends on the concentration of the mercury, its mode of occurrence, the composition of the matrix solution, the material from which the container is made, the previous cleaning and pretreatment of the containers, and, above all, the preservative added or the preservation technique employed. The two mechanisms which are responsible for the loss of mercury from solution are adsorption on to the container walls and volatilization. $\mathrm{Hg}^{\mathrm{II}}$ can be reduced in the presence of a reducing agent, resulting in $\mathrm{Hg}^{0}$ that is able to escape from the solution. Moreover, the formation of undetectable forms of mercury, such as highly stable chemical complexes or stable amalgams after the reduction of oxidized mercury, may also occur (Leermakers et al., 1990).

The most popular types of container material are polyethylene, borosilicate glass and Teflon. Polyethylene containers are not suitable for maintaining low concentrations of mercury; glass is more effective (Bothner and Robertson, 1975; Feldman, 1974; Lo and Wail, 1975). The main preservatives that have been used with good results are 
acids, oxidizing agents and complexing agents. The use of chemical preservatives appears to be necessary in order to maintain mercury concentrations in diluted aqueous solutions. An oxidant such as dichromate or an auric compound is required in a nitric acid medium (Caroli et al., 1996; Coyne and Collins, 1972; Dobb et al., 1994; Feldman, 1974). In any case, random problems in stabilization protocols are always possible, and it is advisable that diluted mercury solutions be prepared and analyzed as quickly as possible to ensure accurate results.

\section{3.-Amalgamation with metals}

All metals can form amalgams with mercury, iron and platinum being notable exceptions. Moreover, $\mathrm{HgCl}_{2}$ is a corrosive species that can also amalgamate with metals, such as aluminium. In order to avoid the loss of analyte through this process, the material used for the analysis of the mercury species needs to be controlled. This includes not only the containers in which samples are stored, but also the other tools and equipment involved in the analysis.

\section{4.- Memory effects and interference}

The memory effect in an analysis of mercury or another element is a problem that originates when species of that element remain somewhere in the equipment, resulting in a positive bias in the subsequent analyses. Inductively coupled plasma-mass spectrometry (ICP-MS) is an example of a technique that often has a pronounced memory effect from mercury. This is due to retention of the mercury in multiple locations: the sample introduction tubes, the nebulizer and the spray chamber (Woller et al., 1997), as well as the torch itself. Different approaches have been tried with ICP-MS analysis to eliminate mercury memory effects. Allibone et al. (1999) found that by adding gold to samples of water analyzed by ICP-MS, the memory effects decrease, but, 
in general, the effectiveness of the procedure depends on the type of sample (Harrington et al., 2004; Moreton and Delves, 1998; Woller et al., 1997).

Interference is a common problem when conducting analyses by cold vapour atomic absorption spectrometry (CVAA). It is due to the presence of a substance that leads to systematic error of a magnitude higher than an established value. The substance that causes the interference distorts the analytical signal, preventing identification of the element or causing an error to occur. In general, interferences depend not only on the analytical method used for the identification or determination, but also on the type of sample. Because each sample has a different composition, the choice of a method that will avoid interferences will depend on the matrix of the sample. A typical example of interference in the analysis of mercury in coal combustion products by (CVAA) is the presence of $\mathrm{SO}_{2}$ by absorbing light at the wavelength being measured.

\section{2. -Samples from coal combustion processes}

The solid samples involved in the coal combustion process are the inputs (the combustible feed and the limestone used in FGD plants) and the outputs or CCBs (bottom ashes, fly ashes, and the gypsum produced in the FGD plants).

The fuel is usually the main source of mercury (Ochoa, et al., 2011). The mercury content of coals all over the world ranges from 0.01 to $1 \mu \mathrm{g} \mathrm{g}^{-1}$ (Yudovich and Ketris, 2005). In so far as trace elements are concerned, the mode of occurrence of mercury has still not been completely ascertained. It is highly probable that the mercury present in most coals is in the form of sulphide or associated with pyrite. Mercury may also be associated with the organic matter in some cases (Yudovich and Ketris, 2005). 
Although data on the mercury content of limestone are relatively scarce, some works have reported values lower than $0.45 \mu \mathrm{g} \mathrm{g}^{-1}$ (Johansen and Hawkins, 2003; Senior and Eddings, 2006). In other studies, the mercury content of limestone reached values as high as $1.11 \mu \mathrm{g} \mathrm{g}^{-1}$ (Lopez-Anton et al., 2011a), suggesting that this input could be an important source of mercury in some FGD plants and, as a consequence, in FGD by-products. There is also a lack of information on mercury speciation in limestone (Johansen and Hawkins, 2003). No correlation between mercury content and pyritic sulphur has been found in limestone samples. Whereas some limestone samples appeared to contain mercury primarily in the form of $\mathrm{HgS}$, others contained $\mathrm{HgSO}_{4}$ and HgO (Senior and Eddings, 2006). Fly ashes showed the largest percentage of CCBs. The mercury content of fly ashes may vary considerably, depending not only on the characteristics of the coal but also on the type of combustion system and boiler used, although it generally ranges between 0.02 and $2 \mu \mathrm{g} \mathrm{g}^{-1}$ (Hower et al., 2010; LopezAnton et al., 2011a). As for the mode of occurrence, mercury can be expected to occur in fly ashes as chlorides, sulphates, associated to the inorganic or carbon particles, or even as elemental mercury (Lopez-Anton et al., 2010).

Bottom ashes or slags have mercury contents that are usually below $0.01 \mu \mathrm{g} \mathrm{g}^{-1}$ (Córdoba et al., 2011), very close to the detection limits of methods used for mercury analysis.

As in the case of fly ash, the mercury content of gypsum varies depending on the characteristics of the power plant, the nature of the coal burned and the performance of the FGD plant. All of these variables may modify the distribution of the mercury retained in the FGD plant between the water and gypsum, and also its speciation. The 
concentration of mercury in the gypsum by-products in the samples analyzed to date has ranged from $<0.01$ to $0.2 \mu \mathrm{g} \mathrm{g}^{-1}$ (Rallo, et al., 2010a; Schroeder and Kairies, 2005).

In addition to the solid samples, it is necessary to analyze the mercury content of the waters involved in the combustion process, such as the water used for preparing the limestone slurry and the water filtered from the gypsum slurry in FGD plants. The mercury content of the gases in the stack also needs to be controlled, and in some cases the air around the power plant needs to be analyzed. In the case of the flue gases, small amounts of $\mathrm{SO}_{2}, \mathrm{H}_{2} \mathrm{O}$ and $\mathrm{NOx}$ may be present, producing interferences in some of the methods used for mercury analysis. For this reason, the equipment and methods need to be carefully selected and controlled.

\section{3. -Analytical methods for the determination and speciation of mercury}

When using any of the analytical methods described in the following sections, the simultaneous determination of certified reference materials (CRMs) is imperative to ensure the quality of the data. Currently, CRMs for different matrices are commercially available from several organizations, including the IAEA (International Atomic Energy Agency, Analytical Quality Control Services), NIST (National Institute of Standards and Technology, Office of Standard Reference Materials, USA) and NRCC (National Research Council of Canada).

\subsection{Solid and liquid samples}

A number of methods for the mercury analysis of solid samples have been developed (Bettinelli et al., 1999; Long and Kelly, 2002; Río-Segade and Bendicho, 1999), and reviews on these analytical methods have already been published. 
The collection of solid samples needs to be carried out following a standard method (such as ASTM D 2013), to obtain a representative sample for analysis. The preparation of the samples does not pose a problem when the method used allows the direct analysis of mercury in the solid sample. However, analytical methods that require the mercury to be in solution must be considered carefully. It should be remembered that coal is a heterogeneous material composed of organic and mineral matter, and the dissolution of mercury from such a product involves the oxidation of the organic matter and the dissolution of the minerals. In most cases organic matter may be eliminated using either wet or dry methods. The dry methods (ashing), even at low temperatures, are not feasible for an element of such high volatility as mercury. Wet methods (Pollock, 1975) need to be performed inside a closed vessel at high or low pressures, in order to avoid any loss of mercury (Bettinelli et al., 1987; Park et al., 2006; Wu et al., 1996).

Among the most common techniques employed today by laboratories for trace element analysis in coal, ICP-MS is the most common, and it is used for mercury analysis due to its excellent sensitivity (theoretically between 1 and $10 \mathrm{pg} \mathrm{ml}^{-1}$ ) (Allibone et al., 1999; Bettinelli et al., 1987; Wilbur, 1999; Wu et al., 1996). However, as already mentioned, this method may pose several problems in relation to the volatility of mercury compounds and the memory effects that, to some extent, restrict its use. For this reason, the conventional methods of measuring total mercury, including neutron activation analysis (NAA), CVAAS and cold vapour atomic fluorescence spectroscopy (CVAFS) are more common.

NAA should not strictly speaking be considered a conventional method due to its high cost (resulting from the need for a nuclear reactor and an expensive counting 
apparatus), and the strict safety requirements for handling radioactive materials. However, this technique is employed by several key laboratories. In NAA, thermal neutrons are irradiated in a nuclear reactor and the gamma radiation from the ${ }^{197} \mathrm{Hg}$ generated is measured by means of comparative quantification with the standard sample. This method allows a non-destructive analysis in which the sample is analyzed directly without the need for any pre-treatment. Its main advantage is that it is very precise and sensitive (Blanchard and Robertson, 1997; Dams, 1992; Olmez, et al., 1993; Olmez et al., 1995).

Cold-vapour (CV) methods use reducing agents, such as $\mathrm{SnCl}_{2}$ or $\mathrm{NaBH}_{4}$, to convert the ionic $\mathrm{Hg}^{\mathrm{II}}$ in solution into $\mathrm{Hg}^{0}$ in gas phase. The liberated $\mathrm{Hg}^{0}(\mathrm{~g})$ is introduced into the absorption cell of an atomic absorption or fluorescence spectrometer where it is detected (Morita, 1995; Price, 1979; Robinson, 1996; Slavin, 1978; Ure, 1975). CV techniques are much more sensitive than conventional flame atomic absorption spectrometry, reaching mercury detection limits as low as 0.01-0.2 $\mathrm{ng} \mathrm{ml}^{-1}$ (Doering et.al., 2000; Mniszek, 1996). The standard CVAAS procedures have been revised and discussed by Pavlish et al. (2003), including Swedish Standard SS 0284 23, US EPA Method 303F (1980), US EPA Method 245.1 and 245.2 (1983), and US EPA 7470 and 7471(1988). The standard procedures based on CVAFS include the US EPA Methods 245.7, 1631 and 7474 and ISO 17852.

The main standard methods used for mercury analysis in coals are: i) ASTM D3684 Bomb Combustion CVAAS; ii) ASTM D6414 Acid Extraction CVAAS iii) ASTM D6414 Wet Oxidation CVAAS; iv) ASTM D6722-01 Direct Combustion Analysis v) US EPA 7471A Acid Extraction CVAAS; and vi) ISO 15237 Bomb Combustion CVAAS. All of them involve detection of mercury by CVAAS, the 
differences being in the method of organic matter oxidation and mercury dissolution. In the ASTM D3684 and ISO 15237 methods, mercury in coal is determined by combusting a weighed sample in an oxygen bomb with diluted nitric acid. In the case of ASTM D6414, and US EPA 7471 the mercury present in coal and CCBs is dissolved by heating the sample in a mixture of acids, which may also contain a catalyst, inside a closed digestion vessel. The acid solutions produced are transferred to a vessel where the mercury is reduced to elemental mercury. In ASTM D6722-01 the sample of coal or CCBs is thermally and chemically decomposed and oxidized in a furnace.

Some researchers claim that the most promising methods for determining mercury in coal are ASTM D3684, ASTM D6414 and ASTM D6722-01 (Sondreal, et al., 2000). Most of these methods can also be used for mercury analysis in materials other than coal. However, gypsum and limestone samples are usually analyzed by means of the US EPA Method 1631 (Kairies et al., 2006). In this method, after digestion of the samples, the total mercury is determined by oxidizing it to $\mathrm{Hg}^{\mathrm{II}}$ with $\mathrm{BrCl}$. The sample is then reduced with $\mathrm{NH}_{2} \mathrm{OH} \cdot \mathrm{HCl}$ to destroy the free halogens, and further reduced with $\mathrm{SnCl}_{2}$ to convert $\mathrm{Hg}^{\mathrm{II}}$ to $\mathrm{Hg}^{0}$. The $\mathrm{Hg}^{0}$ is taken out of the solution either by purging it with nitrogen, helium, argon or by vapour/liquid separation. $\mathrm{The}^{\mathrm{Hg}}{ }^{0}$ is collected in a gold trap and then desorbed into an inert gas stream that channels the mercury into the detection cell of a CVAFS.

The main disadvantage of these methods is that the mercury must be present in a solution and for this reason the use of automatic mercury analyzers (AMA) that allow direct analysis of the solid or liquid sample is the preferred method. These analyses are based on the CV technique which has already been mentioned (ASTM D6722-01). The sample preparation consists simply of weighing it, thereby minimizing contamination 
and errors introduced during the sample preparation of digestive methods (Costley et al., 2000; Richaud et al., 1998). The mercury evaporates from the solid after combustion and decomposition of the sample in an oven, where reduction to elemental mercury also takes place. The mercury in the gas phase is transported to an amalgamator containing gold, retained, and then evaporated and detected as $\mathrm{Hg}^{0}(\mathrm{~g})$. The advantages of this technique are that it can be performed in equipment that is relatively well shielded so as to avoid the loss of mercury, and detection limits as low as $0.01 \mathrm{ng}$ can be attained.

The quality of the results obtained by using AMA (254 Mercury Analyzer (LECO)), has been assessed in a study by Lopez-Anton et al. 2006, using standard samples (two coals and a fly ash). Precise results, statistically indistinguishable from the certificate or reference values, were obtained in the two types of samples (Table 1). The average values of 10 determinations performed by the same operator were compared with the reference or certificate values. The RSD $\%$ was less than $10 \%$ for the fly ash and close to $5 \%$ for the coals (Table 1). These results suggest that the method, in addition to being fast, simple and relatively free of interferences, provides statistically accurate and precise results. There are several types of equipment available on the market, based on the same principle as the US EPA method 7473, 2007. These include the DMA-80 Direct Mercury Analyzer (MILESTONE), the AMA 254 Mercury Analyzer (LECO), the Hydra-C Mercury Analyzer (Teledyne Leeman Labs), and the RA-915+ Mercury Analyzer equipped with the pyrolyzer PYRO-915.

Table 2 provides a comparison of the different techniques that are most frequently used for mercury analysis; ICP-MS, AMA, CVAFS, CVAAS and NAA. The samples analyzed were two reference materials prepared in the laboratory by impregnating a commercial activated carbon with mercury. Impregnation was 
performed in order to obtain samples with a wide range of mercury concentrations; 1 and $10 \mathrm{~g} \mathrm{~g}-1$. The average value of all the analyses was taken as the reference value. In all cases, the relative standard deviations from the result obtained for one of the methods were found to be lower than $10 \%$ of the reference value. The results obtained using the solid sample methods (AMA and NAA) were similar. In general the lowest values were detected by the methods that require dissolution (CVAFS and CVAAS), with the exception of the ICP-MS method, where, apparently, the loss of mercury through volatilization during the preparation was balanced by memory effects.

Identification of mercury species in coal, ashes, and solid products involved in combustion and gas cleaning systems is also a matter of concern from the environmental and research point of view. Mercury speciation in solid samples from coal combustion and their expected concentrations is of great interest, but it is a difficult problem to resolve. X-ray absorption spectroscopy (XAS) and X-ray photoelectron spectroscopy (XPS) are techniques that have been used to identify the speciation and binding of mercury on a variety of materials employed as sorbents for mercury capture in coal combustion processes (Huggins et al., 1999, Huggins et al., 2003; Laumb et al., 2004; Olson et al., 2005, Hutson et al., 2007). However, the use of these techniques to characterize the surface of coals and fly ashes is no easy task, due to the low concentration of mercury in most samples. Mercury analysis by XPS has the added disadvantage of spectral interferences from silicon, which is present in some of these materials (Laumb et al., 2004).

Another method employed for mercury speciation in solid samples is thermally induced desorption. The mercury thermo-desorption technique has been used since 1904 (Aston and Riley, 1972; Henry et al., 1972; Koksoy et al., 1967; Lidums 1972), but only 
recently has it been revived as an important tool in the study of mercury speciation in solid matrices, such as CCBs (Lee et al., 2009; Li et al., 2007; Milobowski et al., 2001; Rallo et al., 2010a; Rallo et al., 2010b). This technique is attractive because different species of mercury can be desorbed over different ranges of temperatures. To define these temperatures, a number of pure mercury compounds $\left(\mathrm{HgCl}_{2}, \mathrm{HgS}, \mathrm{HgSO}_{4}, \mathrm{HgO}\right.$, $\mathrm{Hg}_{2} \mathrm{Cl}_{2}, \mathrm{Hg}_{2} \mathrm{SO}_{4}, \mathrm{HgBr}_{2}$ ) were tested to determine their specific thermograms and obtain a set of "fingerprints" that would serve as a standard of comparison for the profiles resulting from desorption of the CCBs (Milobowski et al., 2001; Lopez-Anton et al., 2010). The temperature rate of the mercury species were arranged in increasing order as follows $\mathrm{HgBr}_{2}<\mathrm{HgCl}_{2}<\mathrm{Hg}_{2} \mathrm{Cl}_{2}<\mathrm{HgS}$ (black) $<\mathrm{Hg}_{2} \mathrm{SO}_{4}<\mathrm{HgS}$ (red) $<\mathrm{HgO}<\mathrm{HgSO}_{4}$ (LopezAnton et al., 2010; Milobowski et al., 2001). In a study of samples obtained from wet FGD processes it was found that the samples showed two thermal decomposition curves (Lopez-Anton et al., 2010). In the case of the first curve it was difficult to tell whether it corresponded to $\mathrm{HgS}$ or $\mathrm{HgO}$, whereas the second clearly corresponded to $\mathrm{HgSO}_{4}$. Lee et al. (2009) tested five standard mercury compounds $\left(\mathrm{Hg}_{2} \mathrm{Cl}_{2}, \mathrm{HgCl}_{2}, \mathrm{HgO}, \mathrm{HgS}\right.$ and $\mathrm{HgSO}_{4}$ ), to compare their thermal evolution profiles and to identify the mercury species present in gypsum and wallboard products. Out of these standards, $\mathrm{Hg}_{2} \mathrm{Cl}_{2}$ and $\mathrm{HgCl}_{2}$ corresponded to the signals observed in the profiles of the samples. This method was also used to identify the mercury species present in fly ashes of different origins that had been used as mercury sorbents in different atmospheres (Lopez-Anton et al., 2011b). The Hg compounds present in a fly ash from a fluidized bed combustion plant after it had been used as a sorbent in an atmosphere of elemental mercury in $\mathrm{N}_{2}$ and in a simulated flue gas from coal combustion were found to be mainly $\mathrm{HgCl}_{2}$ and $\mathrm{HgSO}_{4}$. The Hg species present in two fly ashes from pulverized coal combustion plants was $\mathrm{HgCl}_{2}$, although the presence of $\mathrm{Hg}^{0}$ could not be ruled out, and $\mathrm{HgS}$ was the species 
formed when the ashes were used as a $\mathrm{Hg}$ sorbent in a typical coal gasification atmosphere. Finally, $\mathrm{HgCl}_{2}$ was the only $\mathrm{Hg}$ compound identified in the fly ashes after a sorption experiment in which $\mathrm{HgCl}_{2}(\mathrm{~g})$ was used in all the atmospheres evaluated.

\section{2 - Gases}

The analysis of mercury in gases may be performed by a number of different procedures, some of which allow mercury speciation. It has already been mentioned that, in coal combustion processes, mercury can be found as elemental or oxidized mercury, which affect its degree of removal, atmospheric fate, impact on health and other risks. As a consequence, it is very important to determine the different mercury species in the gas phase. As shown below, there are several ways to sample and analyse mercury in gases. One way is to use a trapping medium, which may be a solution or a train of solutions and a solid or a train of solids that are subsequently analyzed. The other is to use commercially available mercury instruments specially recommended for field measurement. These are devices that allow the simultaneous sampling and analysis of mercury species.

In the early 1990s the Electric Power Research Institute (EPRI) and the U.S. Department of Energy (DOE) initiated very extensive air-toxic characterization programs for electric utilities. These programs included the emission of mercury species. Because there was no validated method for sampling mercury species separately, the U.S. EPA Method 29 and the Bloom method, developed by Brooks Rand (hereafter referred to as the MESA method), were used. The results of these tests showed that, in certain conditions, Method 29 is unable to speciate mercury properly. The US EPA Method 29 allows multi-metal measurements using two sets of impingers to capture mercury in the gas phase. The first set of impingers consists of $\mathrm{HNO}_{3} / \mathrm{H}_{2} \mathrm{O}_{2}$ 
while the second set consists of $\mathrm{KMnO}_{4}$. Method 29 was not designed to speciate mercury, and it has been suggested that only oxidized mercury is captured by the $\mathrm{HNO}_{3} / \mathrm{H}_{2} \mathrm{O}_{2}$ impingers, while the remaining mercury (elemental mercury) is captured in the $\mathrm{KMnO}_{4}$ impingers. The advantages and disadvantages of the impinger method for flue gas mercury determination (e.g. Method 29 and Method 101A) have been discussed elsewhere (Meij, 1991). In general, the main disadvantages of the impinger method are its cost, the hazards involved in the transport of the chemicals, the large volume of sample needed to overcome the high mercury blanks, $\mathrm{SO}_{2}$ interference, and the loss of mercury through the container walls. These disadvantages and the need for mercury speciation prompted the development of the other methods, such as the MESA method (Bloom et al., 1993; Prestbo and Bloom, 1995). The MESA method, designed to speciate flue gas mercury, follows a similar approach to Method 29 except that it uses a different means of capture. This method employs solid sorbent traps consisting of soda lime and iodated carbon to capture oxidized and elemental mercury, respectively. The MESA method is greatly affected by the interaction between $\mathrm{SO}_{2}$ and $\mathrm{NOx}$ in the flue gas, as a result of which the ionic mercury fraction is overestimated (Laudal, et al., 1996b). There were also doubts as to the ability of the MESA method to speciate mercury in flue gas from coal combustion (Chu and Porcella, 1995). After extensive reviews and evaluations (Laudal, et al., 1996a; Laudal, et al., 1997a; Laudal, et al. 1997b), the Ontario Hydro (OH) method has been established as the accepted wetchemical method for measuring total and speciated mercury (ASTM D6784-02). Laboratory and field validations have revealed relative standard deviations of $\sim 10 \%$ (Laudal, 1999). Using this method, three forms of mercury are measured: i) $\mathrm{Hg}_{\mathrm{p}}$, that is separated by filtration; ii) gaseous $\mathrm{Hg}^{\mathrm{II}}$, which is collected in potassium chloride impingers, and iii) gaseous $\mathrm{Hg}^{0}$ that is oxidized and collected in nitric acid/peroxide and 
acidified permanganate solutions. Well-trained personnel are required to use this method, and several restraints must be applied to stabilize the solutions and prevent sample contamination (Sondreal et al., 2000; Sun, et al., 2003). Other methods under development, such as the Solid Ontario Hydro ( $\mathrm{SOH}$ ), use solid reagent cartridges instead of liquid impingers. The results indicate good agreement with the wet $\mathrm{OH}$ method for $\mathrm{Hg}^{0}$ and $\mathrm{Hg}^{\mathrm{II}}$, but particulate mercury cannot be measured (Prestbo and Laudal, 2000). There are a number of commercial sorbent traps which are simple to use and offer precision and accuracy (Laudal, 2006), but SOH, like the $\mathrm{OH}$ method, is not designed for continuous sampling. Most sorbent traps are able to measure total mercury, even if some traps employ multiple sorbents to determine mercury speciation. The U.S. EPA Method 30B is a procedure designed to measure total vapour-phase mercury emissions from coal-fired combustion sources using sorbent trap sampling and an extractive or thermal analytical technique. This method is only intended for use if the presence of particulates is low.

Mercury continuous emission monitors ( $\mathrm{Hg}$ CEMs) are relatively new technologies. They work in a way similar to continuous monitors of other gaseous compounds already operating in power plants. When continuous mercury monitoring is used for mercury speciation problems may arise in conjunction with the quantitative transport of the mercury species from the stack to the mercury detector. Several $\mathrm{Hg}$ CEMs are commercially available (Bergan et al., 1999), some of which have been designed as adaptations of those already used in waste incinerators. However, measuring coal-derived flue gases is more difficult, due to the low mercury concentrations (below $10 \mu \mathrm{g} \mathrm{m}^{-3}$ ) and the presence of fine particulates and gaseous acids, such as $\mathrm{HCl}, \mathrm{SO}_{2}$, and $\mathrm{NO}_{\mathrm{x}}$, that can interfere with the measurements (Laudal et al., 2000). Although $\mathrm{Hg}$ CEMs detect only $\mathrm{Hg}^{0}$, they can be implemented to measure 
total mercury by using a conversion system which reduces the oxidised mercury to elemental mercury. The amount of oxidised mercury can be calculated by difference. The particulate-bound mercury is typically filtered out. This may be important for high particulate-emitting sources (e.g., sources with minimal particulate matter (PM) control), or in cases where the mercury measurements are conducted upstream of PM control devices. As a result, in most commercially available CEMs the total amount of mercury measured is, in fact, total gaseous mercury (TGM). Therefore, the possibility of sampling and analyzing the filtered particles to measure $\mathrm{Hg}_{\mathrm{p}}$ should be a viable procedure.

The options available for the reduction of $\mathrm{Hg}^{\mathrm{II}}$ can be divided into two groups: i) wet conversion using a liquid reducing agent (e.g., stannous chloride); and ii) dry conversion methods (with high temperature catalysts or thermal reduction units to reduce oxidised mercury). The first option is the most established, but wet chemicals are typically corrosive, require frequent renewal and produce hazardous wastes (Laudal et al., 2004; Ryan and Kilgroe, 2001).

The most frequently used methods of differentiating between the Hg CEMs are based on the mercury measurement detection principle: CVAAS, CVAFS, in-situ ultraviolet differential optical absorption spectroscopy (UVDOAS) and atomic emission spectrometry (AES). As with the detection equipment used for mercury analysis in solids, most of the commercially available $\mathrm{Hg}$ CEMs are based on CVAAS or CVAFS.

Several Hg CEM devices are available on the market, the chief characteristics of which are outlined below. The Sir Galahad II (PS Analytical Ltd., 2011) is an automated continuous emission monitor for elemental mercury and total vapour-phase mercury (TGM). It consists of a mercury speciation module and an enclosed cabinet 
which houses an amalgamation atomic fluorescence mercury detector, a stream selector module and a mercury calibration source. The speciation module converts oxidized mercury in the sample gas to elemental mercury by means of a proprietary aqueous reagent, thereby allowing $\mathrm{Hg}^{0}$ and TGM to be detected separately. The Ohio Lumex RA-915+ (Lumex Ltd., 2011) uses catalytic pyrolysis to decompose oxidized mercury to $\mathrm{Hg}^{0}$, which is detected by CVAAS equipped with Zeeman high-frequency polarization background correction. The Lumex CEM is a two-channel instrument, in which one mercury detector operates with the catalytic pyrolyzer and the other without. It is therefore able to provide simultaneous and continuous readings of total and elemental mercury, respectively. The Tekran 2537 (Tekran Instruments Corporation, 2011) samples the gas and traps mercury vapour inside a cartridge containing an ultrapure gold adsorbent. The amalgamated mercury is thermally desorbed and detected using CVAFS. A dual cartridge design allows alternate sampling and desorption, thereby permitting the continuous measurement of the mercury stream. Furthermore, it is designed to be insensitive to the presence of $\mathrm{SO}_{2}, \mathrm{NOx}, \mathrm{CO}_{2}, \mathrm{HCl}$ and other common combustion by-products. The Tekran system also allows simultaneous measurement of $\mathrm{Hg}^{0}$, gaseous $\mathrm{Hg}^{\mathrm{II}}$ and particulate matter (Keeler, et al., 2009). Several round robin studies have reported reliable data via this system (Landis et al., 2002; Munthe et al., 2001), although problems have been observed for speciation in the presence of ozone (Lyman, et al., 2010). The $A M-2$ (Nippon Instruments Corporation, 2011) is another example of a $\mathrm{Hg}^{0}$ pre-concentration and detection system. In this device a flow of sample is drawn through a distilled water scrubbing trap, where oxidized mercury species are removed before reaching a dehumidifier. The sample then passes through a gold amalgamation trap, which collects and concentrates the $\mathrm{Hg}^{0}$. This detection system is a CVAAS. In the DM-6/DM-6P system (Nippon Instruments Corporation, 2011) a 
solid reducing agent is used to reduce $\mathrm{Hg}^{\mathrm{II}}$ to $\mathrm{Hg}^{0}$ by passing the gas through a catalyst bed. After exiting the catalyst, the sample is cooled and then filtered by means of a membrane filter before being transported to the CVAAS detector. The $M S-1 / D M-5$ (Nippon Instruments Corporation, 2011) monitors $\mathrm{Hg}^{0}$ and $\mathrm{Hg}^{\mathrm{II}}$ continuously in gases from the stack, using a speciation unit and two CVAAS detectors, one for $\mathrm{Hg}^{0}$, the other for $\mathrm{Hg}^{\mathrm{II}}$. The Semtech 2010 (Semtech Metallurgy AB, Lund, Sweden, 2011) is essentially a portable Zeeman-modulated CVAAS that is able to monitor $\mathrm{Hg}^{0}$ continuously. The Zeeman-effect background correction system, which combines a modulated magnetic field and a mercury lamp, minimizes interferences from $\mathrm{SO}_{2}$, hydrocarbons, and fine particulates. Semtech offers a wet-chemistry conversion system to reduce $\mathrm{Hg}^{\mathrm{II}}$ to $\mathrm{Hg}^{0}$. However, the conversion system only works if there is no $\mathrm{SO}_{2}$ present in the sample gas. The Opsis HG200 (Opsis AB Furulund, Sweden, 2011) contains a dual gold amalgamation trap followed by a dual beam CVAAS. This system measures the total mercury, reducing the vapour phase $\mathrm{Hg}^{\mathrm{II}}$ to $\mathrm{Hg}^{0}$ by means of a dry thermocatalytic converter. The detection limit, which is $0.5 \mathrm{ng} \mathrm{m}^{-3}$ without the trap, reaches $0.05 \mathrm{ng} \mathrm{m}^{-3}$ with dual amalgamation. The MERCEM (SICK MAIHAK GmbH, Germany, 2011) is also based on gold trap amalgamation and CVAAS and uses $\mathrm{SnCl}_{2}$ reduction to convert $\mathrm{Hg}^{\mathrm{II}}$ to $\mathrm{Hg}^{0}$. The measurement range is $0-45 \mu \mathrm{g} \mathrm{m} \mathrm{m}^{-3}$ and the detection limit is $<1.5 \mu \mathrm{g} \mathrm{m}^{-3}$. In the HM 1400TR device (DURAG, Inc., US, 2011) the gas is sampled by direct extraction and transferred to a dry thermo-reactor for the conversion of $\mathrm{Hg}^{\mathrm{II}}$ to $\mathrm{Hg}^{0}$. Continuous monitoring is based on the principle of CVAAS as detected by a UV Photometer. The dual beam arrangement allowed by a reference cell eliminates any background interference due to $\mathrm{SO}_{2}$ absorption. The detection limit is $0.05 \mu \mathrm{g} \mathrm{m}^{-3}$. The Argus- $\mathrm{Hg} 1000$ (Envimetrics, 2011) measures total mercury with the aid of a catalytic converter which reduces molecular forms of mercury. The mercury is 
pre-concentrated by an absorbent which is thermally desorbed, and is analyzed by exciting the sample using a patented microwave plasma source. The emissions are then detected by a low-resolution ultraviolet spectrometer. The Thermo Electron Mercury Freedom System (Thermo Electron Corporation, 2011) is able to measure $\mathrm{Hg}^{0}, \mathrm{Hg}^{\mathrm{II}}$ and TGM. An advanced CVAFS design provides continuous sample measurement, with no additional gases or pre-concentration required and virtually no interference from $\mathrm{SO}_{2}$. Detection limits as low as $1.0 \mathrm{ng} \mathrm{m}^{-3}$ allow high sample dilution (100:1) and minimize moisture, heat and interfering pollutants. In the Mercury Stack Gas Monitor SM-3 (Mercury Instruments, 2011) forms of mercury such as $\mathrm{HgCl}_{2}, \mathrm{HgO}, \mathrm{HgS}$ and particulate mercury are detected as well as elemental mercury. In this system, the thermo-catalytic reduction of ionic and bound mercury takes place. The gas is then fed into the mercury detector where the mercury is measured by means of CVAAS. The VM-3000 Mercury Vapor Monitor (Mercury Instruments, 2011) measures $\mathrm{Hg}^{0}$ by means of AAS, and does not require an amalgamation step or any expensive carrier gases. The UT-3000 Mercury Vapour Monitor (Mercury Instruments, 2011) combines a GoldTrap amalgamation module with a CVAA detector.

To render $\mathrm{Hg} \mathrm{CEMs}$ eligible for regulatory compliance assurance, their performance needs to have been demonstrated as reliable. During the last 10 years the US Environmental Protection Agency (U.S. Environmental Protection Agency, 2001a, 2001b, 2003a, 2003b, 2003c, 2003c, 2003e, 2007a, 2007b), has undertaken a verification program to evaluate $\mathrm{Hg}$ CEMs at full-scale pilot sites using the $\mathrm{Hg}$ CEMs commercially available in the US, and has compared the results with the $\mathrm{OH}$ method. The most significant results of the verification campaign are presented in Table 3 . Although this is not indicated in Table 3, the results show that almost all the lower readings correspond to the CEMs (U.S. Environmental Protection Agency, 2001a, 
2001b, 2003a, 2003b, 2003c, 2003c, 2003e, 2007a, 2007b). However, good correlations with the $\mathrm{OH}$ method were obtained $(\mathrm{r} 2=0.839-0.989)$ in all cases (Table 3$)$, with the exception of the Lumex CEM. The lack of good correlation in that case was due to the loss of mercury in the inlet systems and the low pyrolyzer temperatures in several of the tests conducted with the Lumex CEM. This device was relatively new when the verification programme was carried out (2011), and during the verification test modifications were introduced by the Lumex staff. From these results it can be concluded that, in general, CEM systems offer a reliable alternative to the $\mathrm{OH}$ method for mercury measurement in industrial applications, with the added advantages that they are simple to use and that measurements can be made on line.

\section{An example of the evaluation and control of mercury in coal power plants}

In order to provide an approximation of the results that can be obtained in a study of mercury behaviour in a power plant, an example of the application of these methods to a real problem (i.e. that of mass balances in power plants) is presented. .In this study, the uncertainty of the results of the analysis for all the products involved in the running of the power plant was calculated and the confidence limits of the results that can be expected from the analytical results are presented. The methods used to carry out this evaluation are among the most commonly used. To determine the amount of mercury in coal and CCBs, direct combustion analysis (ASTM D6722-01) performed using the different instruments previously described is the main procedure. Acid extraction or wet oxidation/CVAA (ASTM D6414-01) for other solid and liquid samples is also a widely used procedure. In addition, the Ontario Hydro method (ASTM D6784-02) is the standard method for the analysis of mercury species in a gas stream. All these methods were used for the analysis of mercury in the products involved in coal 
combustion in two pulverized power plants, one of which was equipped with a flue gas desulphurization (FGD) system. Table 4 shows the mercury contents along with the degree of uncertainty for the analysis of these products. The results and uncertainty were calculated according to the ASTM D6722-01 method for solid (coal, bottom ash, fly ash, and gypsum) and liquid (water) samples because it was possible to analyze these samples directly using an automatic mercury analyzer and they fell within the appropriate range of concentration for this method. The results and uncertainty for the particulate matter were determined using the ASTM D6414-01 method after acid digestion in a microwave oven. With the $\mathrm{OH}$ method an acceptable degree of uncertainty is $<11 \%$ for mercury concentrations in a gas phase of $>3 \mu \mathrm{g} \mathrm{m}^{-3}$ and $<34 \%$ for mercury concentrations in a gas phase of $<3 \mu \mathrm{g} \mathrm{m}{ }^{-3}$. In the gas analyses presented in Table 4, the confidence limits were of this order in both cases. For the rest of the samples, solids and liquids, the limits of confidence in the analysis of solid samples are of the same order. Consequently, if the percentage of products found in each power plant after combustion are examined (\% out values in Table 4$)$, the highest degree of uncertainty associated with the analytical procedure corresponds to the analysis of the samples with the highest proportion of mercury. In the case of the power plant without an FGD unit this was the analysis of the gases, whereas in the power plant with an FGD system this was the analysis of the gypsum samples

\section{Conclusions}

The analysis of the products and by-products involved in the processes of energy production from coal (coal, ashes, limestone, gypsum, water and gases) is an indispensable tool for controlling and preventing environmental problems that may be 
initiated by emissions of mercury compounds. The characteristics of mercury compounds are such that, whatever the analytical method used, the strictest precautions need to be taken to prevent the loss of, and contamination by, mercury species during the analytical procedure. Once this has been achieved, the analysis of the total mercury species in solid and liquid products offers no problem. User-friendly equipment that meets the standards for analysis of total mercury in solid and liquid products is readily available. The analysis of mercury in the flue gas of combustion plants is more difficult. Although equipment for the analysis of gas samples can be found on the market, it is not always free of interferences.

However, unarguably the biggest problem related with mercury analysis, both in general and with coal and coal combustion by-products in particular, is that of identifying the species of mercury present in the samples. This is where there is a need for further analytical development.

\section{Acknowledgments}

The work was financed by the project CTM2004-04252-CO2-02/TECHNO. We would like to acknowledge the support of CSIC for providing M. Antonia López-Antón with a postdoctoral position, and of FICYT (Asturias Research Programme) for funding a doctoral fellowship for Raquel Ochoa-González and the project PC10-20. 


\section{References}

Allibone, J., Fatemian, E., Walker, P.J., 1999. Determination of mercury in potable water by ICP-MS using gold as a stabilising agent. Journal of Analytical Atomic Spectrometry 14, 235-239.

Ariya, P. A., Peterson, K., Snider, G., Amyot, M., 2009. Mercury Fate and Transport in the Global Atmosphere. Pirrone, N. Mason, R. Eds. Springer, New York, pp. 459-501, DOI: 10.1007/978-0-387-93958-2_15.

ASTM, 2001. ASTM D6722: Standard Test Method for Total Mercury in Coal and Coal Combustion Residues by Direct Combustion Analysis

ASTM, 2006. ASTM D3684: Standard Test Method for Total Mercury in Coal by the Oxygen Bomb Combustion/Atomic Absorption Method

ASTM, 2006. ASTM D6414: Standard Test Methods for Total Mercury in Coal and Coal Combustion Residues by Acid Extraction or Wet Oxidation/Cold Vapor Atomic Absorption

ASTM, 2008. ASTM D6784: Standard Test Method for Elemental, Oxidized, Particle-Bound and Total Mercury in Flue Gas Generated from Coal-Fired Stationary Sources (Ontario Hydro Method)

ASTM, 2011. ASTM D2013 - D2013M: Standard Practice for Preparing Coal Samples for Analysis

Aston, S.R., Riley, J.P., 1972. The determination of mercury in rocks and sediments. Analytica Chimica Acta 59, 349-354. 
Bergan, F. N., Priebe, S.J., Haas, H.J. Jr., 1999. State of the art - Mercury CEMs, Analytical Chemistry 71, 470A-475A.

Bettinelli, M., Baroni, U., Pastorelli, N., 1987. Analysis of coal fly ash and environmental materials by inductively coupled plasma atomic emission spectrometry: comparison of different decomposition procedures. Journal of Analytical Atomic Spectrometry 2, 485-489.

Bettinelli, M., Spezia, S., Roberti, S., 1999. Determination of mercury in coal using FI-CVAAS and FI-CV-ICP-MS, Atomic Spectroscopy 20, 13-19.

Blanchard, L.J., Robertson, J.D., 1997. Determination of mercury in coal using radiochemical methods. Analysis 122, 1261- 1264.

Bloom, N., Presto, E., Miklavic, V., 1993. Flue Gas Mercury Emissions and Speciation from Fossil Fuel Combustion. Presented at the Second EPRI International Conference on Managing Hazardous Air Pollutants, Washington, D.C.

Bothner, M.H., Robertson, D.E., 1975. Mercury contamination of sea water samples stored in polyethylene containers. Analytical Chemistry 47, 592-595.

Caroli, S., Forte, G., Iamiceli, A.L., Lusi, A., 1996. Stability of mercury dilute aqueous solutions: An open issue. Microchemical Journal 54(4), 418-428.

Chu, P., Porcella, D. B., 1995. Mercury stack emissions from U.S. electric utility power plants. Water Air and Soil Pollution 80, 135-144.

Córdoba, P., Font, O., Izquierdo, M., Querol, X., Tobías, A., López-Antón, M.A., Ochoa-Gonzalez, R., Díaz-Somoano, M., Martínez-Tarazona, M.R., Ayora, C., Leiva, C., Fernández, C., Giménez, 2011. A. Enrichment of inorganic trace pollutants in 
re-circulated water streams from a wet limestone flue gas desulphurisation system in two coal power plants. Fuel Processing Technology 92, 1764-1775.

Costley, C.T., Mossop, K.F., Dean J.R., Garden, L.M., Marshall, J., Carroll, J., 2000. Determination of mercury in environmental and biological samples using pyrolysis atomic absorption spectrometry with gold amalgamation. Analytica Chimica Acta 405, 179-183.

Coyne, R V. and Collins, J A., 1972. Loss of mercury from water during storage. Analytical Chemistry 44, 1093- 1096.

Dams, R., 1992. A critical review of nuclear activation techniques for the determination of trace elements in atmospheric aerosols, particulates and sludge samples. Pure and Applied Chemistry 64, 991- 1014.

Dobb, D. E., Metcalf, R. C., Gerlach, R. W., Butler, L. C., 1994. Optimizing reactions for preserving mercury with gold chloride in environmental water samples, Emerging Technologies in Hazardous Waste Management VI, 1438-1441.

Doering, W.E., James, R.R., Echols, R.T., 2000. A sequential injection coldvapor atomic absorption method for the determination of total mercury, Fresenius Journal of Analytical Chemistry 368, 475-179.

DURAG, Inc., US, www.durag.com. Accessed July 2011

Envimetrics, www.envimetrics.com. Accessed July 2011

Feldman, C., 1974. Preservation of dilute mercury solutions. Analytical Chemistry 46, 99-102. 
Harrington, C.F., Merson S A., D' Silva T M., 2004. Method to reduce the memory effect of mercury in the analysis of fish tissue using inductively coupled plasma mass spectrometry. Analytica Chimica Acta 505, 247-254.

Hassett, D. J., Heebink, L. V., Pflughoeft-Hassett, D. F, 2002. Potential for Mercury Release from Coal Combustion By-Products. Proceedings of Conference on Air Quality III: Mercury, Trace Elements, and Particulate Matter Conference. Energy \& Environmental Research Center: Grand Forks, North Dakota. http://www.netl.doe.gov/publications/proceedings/02/air_q3/eerc.pdf

Hassett, D. J., Heebink, L. V., Pflughoeft-Hassett D.F., 2004. Potential for mercury vapor release from coal combustion by-products. Fuel Processing Technology $85,613-620$.

Heebink, L. V., Hassett, D. J., 2004. Evaluation of coal combustion byproduct mercury release potential. Preprint Papers - American Chemical Society, Division of Fuel Chemistry $49,221$.

Heebink, L.V., Hassett D. J., 2005. Mercury release from FGD. Fuel 84, 13721377.

Henry, H.G., Stever K.R., Heady, H.H., 1972. Determination of mercury in lowgrade ores. Applied. Spectroscopy 26, 288-293.

Hower, J.C., Senior, C.L., Suuberg, E.M., Hurt R.H., Wilcox J.L., Olson, E.S., 2010. Mercury capture by native fly ash carbons in coal-fired power plants. Progress in Energy Combustion Science 36, 510-529. 
Huggins, F. E., Huffman, G. P., Dunham, G. E., Senior, C. L., 1999. XAFS examination of mercury sorption on three activated carbons. Energy and Fuels 13, 114121.

Huggins, F. E., Yap, N., Huffman, G. P., Senior, C. L., 2003. XAFS characterization of mercury captured from combustion gases on sorbents at low temperatures. Fuel Processing and Technology 82, 167-196.

Hutso,n N D., Attwood, B C., K G. Scheckel., 2007. XAS and XPS characterization of mercury binding on brominated activated carbon. Environmental Science and Technology 41, 1747-1752.

ISO 15237, 2003. ISO 15237: Solid mineral fuels - Determination of total mercury content of coal

ISO 17852. 2006. ISO 17852: Water quality - Determination of mercury Method using atomic fluorescence spectrometry

Johansen, V. C., Hawkins, G. J., 2003. Mercury Speciation in Cement Kilns: A Literature Review, R\&D Serial No. 2567, Portland Cement Association, Skokie, Illinois, USA, 16 p.

Kairies, C.L., Schroeder, K.T., Cardone, C.R., 2006. Mercury in gypsum produced from flue gas desulfurization. Fuel 85, 2530-2536.

Keeler, G. J., Pirrone, N., Bullock, R., Sillman S., 2009. The need for a coordinated global $\mathrm{Hg}$ monitoring network for global and regional models validation. Earth and Environmental Science. In: Mason, R., Pirrone, N. (eds), Mercury Fate and Transport in the Global Atmosphere, pp 391-424 DOI: 10.1007/978-0-387-93958-2_13. 
Koksoy, M., Bradshaw, P.M.D., Tooms, J.S., 1967. Notes on the determination of mercury in geological samples. Transactions of the Institution of Mining and Metallurgy, Section B 76, b121-b124.

Landis, M.S., Stevens, R.K., Schaedlich, F., Prestbo, E.M., 2002. Development and characterization of an annular denuder methodology for the measurement of divalent inorganic reactive gaseous mercury in ambient air. Environmental Science and Technology 36, 3000-3009.

Laudal, D.L., Galbreath, K.C., Heidt, M.K., Brown, T.D., Nott, B.R., Jones, S.K., 1996a. A State-of-the-Art Review of Flue Gas Mercury Speciation Methods. EPRI/DOE Final Report, EPRI TR-107080.

Laudal, D.L., Heidt, M.K., Brown, T.D. and Nott, B.R., 1996b. Mercury Speciation: A Comparation Between Method 29 and Other Sampling Methods. Presented at the 89 Annual Meeting of the Air and Waste Management Association, Nashville, TN, Paper 96-W64A.04.

Laudal, D.L., Heidt, M.K., Nott B.R. and Brown, T.D., 1997a. Evaluation of Flue Gas Mercury Speciation Methods. EPRI/DOE Final Report, EPRI TR-108988.

Laudal, D.L., Heidt, M.K., Nott, B.R. and Brown, T.D., 1997b. Recommended methods for mercury speciation measurements in coal combustion systems. Presented at the Fourth International Conference Managing Hazardous Air Pollutants.

Laudal, D.L., 1999. Field Validation of the Ontario Hydro Mercury Speciation Sampling Method at Site E-29. Electric Power Research Institute/U.S. Department of Energy Final Report. 
Laudal, D.L., Brown, T. D., Nott, B. R., 2000. Effects of flue gas constituents on mercury speciation. Fuel Processing Technology 65-66, 157-165.

Laudal, D.L., Thompson, J.S., Pavlish, J.H., Brickett, L.A., Chu, P., 2004. Use of continuous mercury monitors at coal-fired utilities. Fuel Processing Technology 85, $501-511$.

Laudal, D.L., 2006. The use of sorbent traps as a reference method for mercury measurement. DOE/NETL Mercury Control Technology Conference http://www.netl.doe.gov/publications/proceedings/06/mercury/presentations/Laudal_pre sentation 121306.pdf. Accessed July 2011.

Laumb, J. D., Benson, S. A., Olson, E. A., 2004. X-ray photoelectron spectroscopy analysis of mercury sorbent surface chemistry. Fuel Processing Technology 85, 577-585.

Lee, J.-Y., Cho, K., Cheng, L., Keener, T.C., Jagadeesan, G., Al-Abed, S., 2009. Investigation of a mercury speciation technique for flue gas desulfurization materials. Journal of the Air and Waste Management Association 59, 972-979.

Leermakers, M, P. Lansens, P. and W. Baeyens, 1990. Storage and stability of inorganic and methylmercury solutions. Fresenius Journal of Analytical Chemistry, 336, $655-662$.

Li J., Yuan, Y., Perry, R., Maroto-Valer, M.M., 2007. Thermal desorption and speciation of mercury in fly ash. Preprint Papers - American Chemical Society, Division of Fuel Chemistry 52, 511-512. 
Lidums, V., 1972. Determination of mercury in small quantities by direct combustion combined with cold vapor-atomic absorption. Chemica Scripta 2, 159-163.

Lo, J. M. and Wail, C. M., 1975. Mercury loss from water during storage: mechanisms and prevention. Analytical Chemistry 47 1869-1870.

Long, S E., Kelly, W. R., 2002. Determination of mercury in coal by isotope dilution cold-vapor generation inductively coupled plasma mass spectrometry. Analytical Chemistry 74, 1477-1483.

Lopez-Anton, M.A., Diaz-Somoano, M., Diaz, L., Martinez-Tarazona M.R. 2011a. Avoiding mercury emissions by combustion in a Spanish circulating fluidizedbed combustion (CFBC) plant. Energy \& Fuels 25, 3002-3008.

Lopez-Anton, M.A., Diaz-Somoano, M., García, A.B., Martínez-Tarazona, M.R., 2006. Evaluation of mercury associations in coal using physical separation procedures. Fuel 85, 1389-1395.

López-Antón, M.A., Perry, R., Abad-Valle, P., Díaz-Somoano, M., MartínezTarazona, M.R., Maroto-Valer, M. M., 2011b. Speciation of mercury in fly ashes by temperature programmed decomposition. Fuel Processing Technology 92, 707-711.

Lopez-Anton, M.A., Yuan, Y., Perry, R., Maroto-Valer, M.M., 2010. Analysis of mercury species present during coal combustion by thermal desorption. Fuel 89, 629634.

Lumex Ltd., www.ohiolumex.com. Accessed July 2011 
Lyman, S. N., Jaffe, D. A., and Gustin, M. S., 2010. Release of mercury halides from $\mathrm{KCl}$ denuders in the presence of ozone, Atmospheric Chemistry and Physics 10, $8197-8204$

Meij, R. 1991. A sampling method based on activated carbon for sampling gaseous mercury in ambient air and flue gases. Water, Air and Soil Pollution 56, 117 129.

Mercury Instruments, www.mercury-instruments.com. Accessed July 2011

Milobowski, M.G., Amrhein, G.T., Kudlac, G.A., Yurchison, D.M., 2001. Wet FGD enhanced mercury control for coal-fired utility boilers, The U.S. EPA/DOE/EPRI Combined Power Plant Air. Pollutant Control Symposium: "The Mega Symposium" Chicago, Illinois, USA. http://www.babcock.com/library/pdf/BR-1716.pdf Accessed July 2011

Mniszek, W., 1996. Cold vapour atomic absorption spectrometry for total mercury determination in coal sample after oxygen combustion. Chemia Analityczna (Warsaw) 41, 269-274.

Moreton, J.A., Delves H.T., 1998. Simple direct method for the determination of total mercury levels in blood and urine and nitric acid digests of fish by inductively coupled plasma mass spectrometry. Journal of Analytical Atomic Spectrometry 13, $659-665$.

Morita, H., Tanaka, H., Shimomura, S., 1995. Review: Atomic fluorescence spectrometry of mercury: principles and developments. Spectrochimica Acta 50B 6984. 
Munthe, J., Wangberg, I. ,Pirrone, N., Iverfeld A., Ferrara, R. Ebinghaus, R., Feng., R., Gerdfelt K. Keeler, G.J., Lanzillotta, E. ,Lindberg ,S.E., Lu, J., 2001. Intercomparison of methods for sampling and analysis of atmospheric mercury species. Atmospheric Environment 35, 3007-3017.

Nippon Instruments Corporation, www.hg-nic.com. Accessed July 2011

Ochoa-González, R., Córdoba, P., Díaz-Somoano, M., Font, O., López-Antón, M. A., Leiva, C., Martínez-Tarazona, M. R., Querol, X., Fernández, C., Tomás, A., Gómez, P. Pesado P., 2011. Differential partitioning and speciation of Hg in wet FGD facilities of PCC power plants. Chemosphere 85, 565-570

Olmez, I., Ames, M., Aras N.K., 1993. Mercury determination in environmental materials: Methodology for instrumental neutron activation analysis. Conference Proceedings: The Measurement of Toxic and Related Air Pollutants, U.S. Environmental Protection Agency, Durham, NC.

Olmez, I., Huang, X., Ames, M.R., 1995 . The role of instrumental neutron activation in environmental mercury analysis. Presented at the 88th Annual Meeting and Exhibition of the Air and Waste Management Association, San Antonio, TX, Paper 95MP21.02.

Olson, E. S., Crocker, C. R., Benson, S. A., Pavlish, J. H., Holmes, M. J., 2005. Surface compositions of carbon sorbents exposed to simulated low-rank coal flue gases. Journal of the Air Waste Management Association 55, 747-754.

Opsis AB Furulund, Sweden, www.opsis.se. Accessed July 2011

Pacyna, E.G., Pacyna, J.M., Sundseth, K., Munthe, J., Kindbom, K., Wilson, S., Steenhuisen, F., Maxson, P, 2010. Global emission of mercury to the atmosphere from 
anthropogenic sources in 2005 and projections to 2020. Atmospheric Environment 44, 2487-2499.

Park, J.Y, Won, J.H., Lee, T.G., 2006. Mercury analysis of various types of coal using acid extraction and pyrolysis methods. Energy \& Fuels 20, 2413-2416.

Pavlish, J.H., Sondreal, E.A., Mann, M.D., Olson, E.S., Galbreath, K.C., Laudal, D.L., Benson, S.A, 2003. Status review of mercury control options for coal-fired power plants. Fuel Processing Technology 82, 89-165.

Pirrone, N., Cinnirella, S., Feng, X., Finkelman, R.B., Friedli, H.R., Leaner, J., Mason, R., Mukherjee, A.B., Stracher, G.B., Streets, D.G., Telmer, K., 2010. Global mercury emissions to the atmosphere from anthropogenic and natural sources. Atmospheric Chemiastry and Physics 10, 5951-5964.

Pollock, E. N., 1975. Trace impurities in coal by wet chemical methods. in Trace Elements in Fuel Ed: :Suresh P. Babu Volume 141, Chapter 2, 23-34.

Price, W.J., 1979. Spectrochemical Analysis by Atomic Absorption, Heyden \& Son, London, UK, $392 \mathrm{pp}$

Prestbo, E. M., Bloom, N S., 1995. Mercury speciation adsorption (MESA) method for combustion flue gas: Methodology, artefacts, intercomparison and atmospheric implications. Water, Air and Soil Pollution 80, 145-158.

Prestbo, E.M., Laudal, D.L., 2000. Investigation of the fate of mercury in a coal combustion plume using a static plume dilution chamber. Proceedings of Air Quality II: Mercury, Trace Elements, and Particulate Matter Conference, McLean, VA, Paper A55. 
PS Analytical Ltd., www.psanalytical.com. Accessed July 2011

Rallo, M., Lopez-Anton, M.A., Perry, R., Maroto-Valer, M.M., 2010a. Mercury speciation in gypsums produced from flue gas desulfurization by temperature programmed decomposition. Fuel 89, 2157-2159.

Rallo, M., Lopez-Anton, M.A., Meij, R., Perry R., Maroto-Valer ,M.M., 2010 b. Study of mercury in by-products from a Dutch co-combustion power station, Journal of Hazardous Materials 174, 28-33.

Richaud, R., Lachas, H., Collot, A., Mannerings, A.G., Herod, A.A., Dugwell, D.R., Kandiyoti, R., 1998. Trace mercury concentrations in coals and coal-derived material determined by atomic absorption spectrophotometry. Fuel 77, 359-368.

Río-Segade, S., Bendicho, C., 1999. Slurry sampling combined with ultrasonic pretreatment for total mercury determination in samples containing inorganic and methylmercury by flow injection-cold vapor-atomic absorption spectrometry Journal of Analytical Atomic Spectrometry. 14, 1907-1912.

Robinson, J.W., 1996. Atomic Absorption Spectroscopy. Marcel Dekker Inc., New York 204p.

Rubel, A.M., Hower, J.C., Mardon, S.M., Zimmerer, M.J., 2006. Thermal stability of mercury captured by ash. Fuel $85,2509-2515$.

Ryan, J.V., Kilgroe, J.D., 2001. Mercury CEMs: Technology update. 9th Annual North American Waste to Energy Conference, ASME, 171-175. 
Schroeder, K., Kairies, C., 2005. Distribution of mercury in FGD byproducts. World of Coal Ash (WOCA) Lexington, Kentucky, USA. http://www.flyash.info/2005/100sch.pdf Accessed July 2011

Schuster, E., 1991. The behaviour of mercury in the soil with special emphasis on complexation and adsorption processes - A review of the literature. Water, Air, and Soil Pollution: 56: 667-680,

Semtech Metallurgy AB, Lund, Sweden, www.semtech.se. Accessed July 2011

Senior, C. and Eddings, E., 2006. Evolution of Mercury from Limestone.Report Portland Cement Association, PCA R\&D Serial No. 2949, 19 pp

SICK MAIHAK GmbH, Germany, http://www.sick.com. Accessed July 2011

Slavin, M., 1978. Atomic Absorption Spectroscopy, 2nd ed., Wiley, New York, $193 p$.

Sondreal, E.A., Benson, S.A., Pavlish, J.H. Galbreath, K.C., Zygarlicke, C.J., Thompson, J.S., McCollor, D.P., Crocker, C.R., Lillemoen, C.M., Mann, M.D., Jensen, R.R., Weber, G.F., 2000. Center for Air Toxic Metals Final Technical Report Volume 3; Final Technical Report for U.S. Environmental Protection Agency Assistance Agreement R824854; Energy \& Environmental Research Center: Grand Forks, ND.

Swedish Standards 1991. SS 0284 23. SIS, Luftunderso“knogar- Utslag“upp till luft- Bestämning av total kvicksilverhalten med flamlo"s atomabsorptionsmetod (Air quality- stationary source emissions- determination of the total mass concentration of mercury - flameless atomic absorption methods, Stockholm, Sweden, Standardiseringskommissioneni Sverige, 1991, Dec., p. 11, (in Swedish). 
Sun, J Q., Uhrich, K S., Schulz, R L., 2003. Evaluation of mercury stability in ontario hydro method solutions for mercury speciation in flue gas generated from coalfired stationary sources. Preprint Papers - American Chemical Society, Division of Fuel Chemistry 48(2), 774-776.

Tekran Instruments Corporation, www.tekran.com. Accessed July 2011

Thermo Electron Corporation, www.thermo.com Accessed July 2011

UNEP, 2008. United Nations Environment Programme The Global Atmospheric Mercury Assessment: Sources, Emissions and Transport, Geneva, 200844 p,. www.chem.unep.ch/mercury. Accessed July 2011

UNEP, 2010a. Reducing Mercury Emissions from Coal Combustion in the EnergySector.http://www.unep.org/hazardoussubstances/Mercury/PrioritiesforAction/C oalcombustion/activities/tabid/4491/language/enUS/Default.aspx. Accessed July 2011.

UNEP, 2010b. Process Optimization Guidance Document for Reducing Mercury Emissions from Coal Combustion in Power Plants. Chemical Branch, DTIE, Geneva, Switzerland, Draft report.

http://www.unep.org/hazardoussubstances/Mercury/PrioritiesforAction/Coalcombustion /activities/tabid/4491/language/enUS/Default.aspx. Accessed July 2011.

Ure, A.M., 1975. The determination of mercury by non-flame atomic absorption and fluorescence Spectrometry: A review. Analytical Chimica. Acta 76, 1- 26. http://www.chem.agilent.com/Library/flyers/Public/hs9901-2.pdf Accessed July 2011

U.S. Environmental Protection Agency, 1983. EPA Method 245.1 and 245.2.: Methods of Chemical Analysis of Water and Wastes, Cincinnati, OH, 1983, EPA$600 / 4-82-05$ 
U.S. Environmental Protection Agency, 1988. EPA 7470 and 7471: Test Methods for Evaluating Solid Waste: Physical/Chemical Methods, 3rd ed., Washington, DC, 1988, Sept., SW-846

U.S. Environmental Protection Agency, 1980. EPA Method 303F: Determination of Mercury by the Cold Vapor Technique.

U.S. Environmental Protection Agency, 2001a. Environmental Technology Verification (ETV) Program,. www.epa.gov/nrmrl/std/etv/pubs/01_vs_nippon_am2.pdf. Accessed July 2011.

U.S. Environmental Protection Agency, 2001b. Environmental Technology Verification (ETV) Program, www.epa.gov/nrmrl/std/etv/pubs/01 vs lumex cem.pdf. Accessed July 2011.

US Environmental Protection Agency, 2002. EPA Methods 1631 Method 1631, Revision E: Mercury in Water by Oxidation, Purge and Trap and Cold Vapor Atomic Fluorescence Spectrometry August

U.S. Environmental Protection Agency 2003a. Environmental Technology Verification (ETV) Program, 2003. www.epa.gov/nrmrl/std/etv/pubs/01_vs_argus.pdf. Accessed July 2011.

U.S. Environmental Protection Agency, 2003b. Environmental Technology Verification (ETV) Program, www.epa.gov/nrmrl/std/etv/pubs/01_vs_nippon_dm6.pdf. Accessed July 2011. 
U.S. Environmental Protection Agency, 2003c. Environmental Technology Verification (ETV) Program,. www.epa.gov/nrmrl/std/etv/pubs/01_vs_nippon_dm5.pdf. Accessed July 2011.

U.S. Environmental Protection Agency, 2003d. Environmental Technology Verification (ETV) Program, www.epa.gov/nrmrl/std/etv/pubs/01_vs_nippon_dm5.pdf. Accessed July 2011.

U.S. Environmental Protection Agency, 2003e. Environmental Technology Verification (ETV) Program, www.epa.gov/nrmr1/std/etv/pubs/01_vs_psa_sg2.pdf. Accessed July 2011.

U.S. Environmental Protection Agency, 2007a. Environmental Technology Verification (ETV) Program,. www.epa.gov/nrmrl/std/etv/pubs/600etv07009s.pdf. Accessed July 2011.

U.S. Environmental Protection Agency, 2007b. Environmental Technology Verification (ETV) Program, www.epa.gov/nrmrl/std/etv/pubs/600etv07010s.pdf. Accessed July 2011.

US Environmental Protection Agency, 2007c. US EPA Methods 7474 Mercury in Sediment and TissueISSUE Samples By Atomic Fluorescence Spectrometry

US Environmental Protection Agency, EPA 2007. US EPA Method 7473:Mercy;ury in Solids and Solutions by Thermal Decomposition ,Amalgamation and Atomic Absorption Spectrophotometry 
US Environmental Protection Agency, US EPA Method 29:Determination of OF Metals Emissions From Stationary Sources, www.epa.gov/ttn/emc/promgate/m29.pdf.

US Environmental Protection Agency, US EPA Method 101A: Detremination of Particulate and Gaseous Mercury Emissions From Sewage Sludge Incinerators. www.epa.gov/ttn/emc/promgate/m-101a.pdf.

U.S. Environmental Protection Agency, US EPA Method 30B: Determination of total vapour phase mercury emissions from coal fired combustion sources using carbon sorbent traps. www.epa.gov/ttn/emc/promgate/Meth30B.pdf. Accessed December 2011. Wilbur, S., 1999. Direct analysis of mercury using ICP-MS. HP ICP-MS Newsletter 2-7.

Woller, A., Garraud, H., Martin, F., Donard, O.F.X., Fodor, P., 1997. Determination of total mercury in sediments by microwave assisted digestion flow injection inductively coupled plasma mass spectrometry. Journal of Analytical Atomic Spectrometry $12,53-56$.

Wu, S., Zhao, Y., Feng, X., Wittmeier, A., 1996. Application of inductively coupled plasma mass spectrometry for total metal determination in silicon containing solid samples using the microwave-assisted nitric acid-hydrofluoric acid-hydrogen peroxide-boric acid digestion system. Journal of Analytical Atomic Spectrometry 11, 287-296.

Yudovich, Y. E., Ketris, M.P., 2005. Mercury in coal: A review, Part 1. Geochemistry. International Journal of Coal Geology 62, 107- 134. 
Table 1.-Results obtained from the analysis of mercury using AMA equipment

\begin{tabular}{llll}
\hline & $\begin{array}{c}\text { SARM19 } \\
\text { (coal) }\end{array}$ & $\begin{array}{c}\text { SARM20 } \\
\text { (coal) }\end{array}$ & $\begin{array}{c}\text { 1633b } \\
\text { (fly ash) }\end{array}$ \\
\hline $\mathrm{n}$ & 10 & 10 & 10 \\
$\mathrm{ref} . / \mathrm{cert}\left(\mu \mathrm{g} \mathrm{g}^{-1} \mathrm{Hg}\right)$ & 0.2 & 0.25 & 0.14 \\
$\mathrm{x}\left(\mu \mathrm{g} \mathrm{g}^{-1} \mathrm{Hg}\right)$ & 0.23 & 0.25 & 0.15 \\
$\mathrm{SD}$ & 0.010 & 0.013 & 0.014 \\
$\mathrm{RSD} \%$ & 4.3 & 5.2 & 9.3 \\
\hline
\end{tabular}

Table 2. Comparison of mercury analyses obtained by different techniques (average values of two replicates)

\begin{tabular}{l|c|ccccc}
\hline & $\begin{array}{c}\text { Reference } \\
\left(\mu \mathrm{g} \mathrm{g}^{-1}\right)\end{array}$ & $\begin{array}{c}\text { ICP-MS } \\
\mu \mathrm{g} \mathrm{g}^{-1}\end{array}$ & $\begin{array}{c}\text { AMA } \\
\mu \mathrm{g} \mathrm{g}^{-1}\end{array}$ & $\begin{array}{c}\text { CVAFS } \\
\mathrm{gg} \mathrm{g}^{-1}\end{array}$ & $\begin{array}{c}\text { CVAAS } \\
\mathrm{gg} \mathrm{g}^{-1}\end{array}$ & $\begin{array}{c}\text { NAA } \\
\mathrm{g} \mathrm{g}^{-1}\end{array}$ \\
\hline CA1 & $\mathbf{1 . 1 5}$ & 1.22 & 1.21 & 1.07 & 1.05 & 1.20 \\
CA10 & $\mathbf{1 1 . 5}$ & 12.4 & 10.9 & 10.6 & 11.2 & 11.1 \\
\hline
\end{tabular}

CA 1 and CA 2 are synthetic samples prepared from impregnation of an activated carbon with mercury. 
Table 3. Results form the Quality Assurance (QA) study carried out through verification testing (U.S. Environmental Protection Agency, 2001, 2003, 2007).

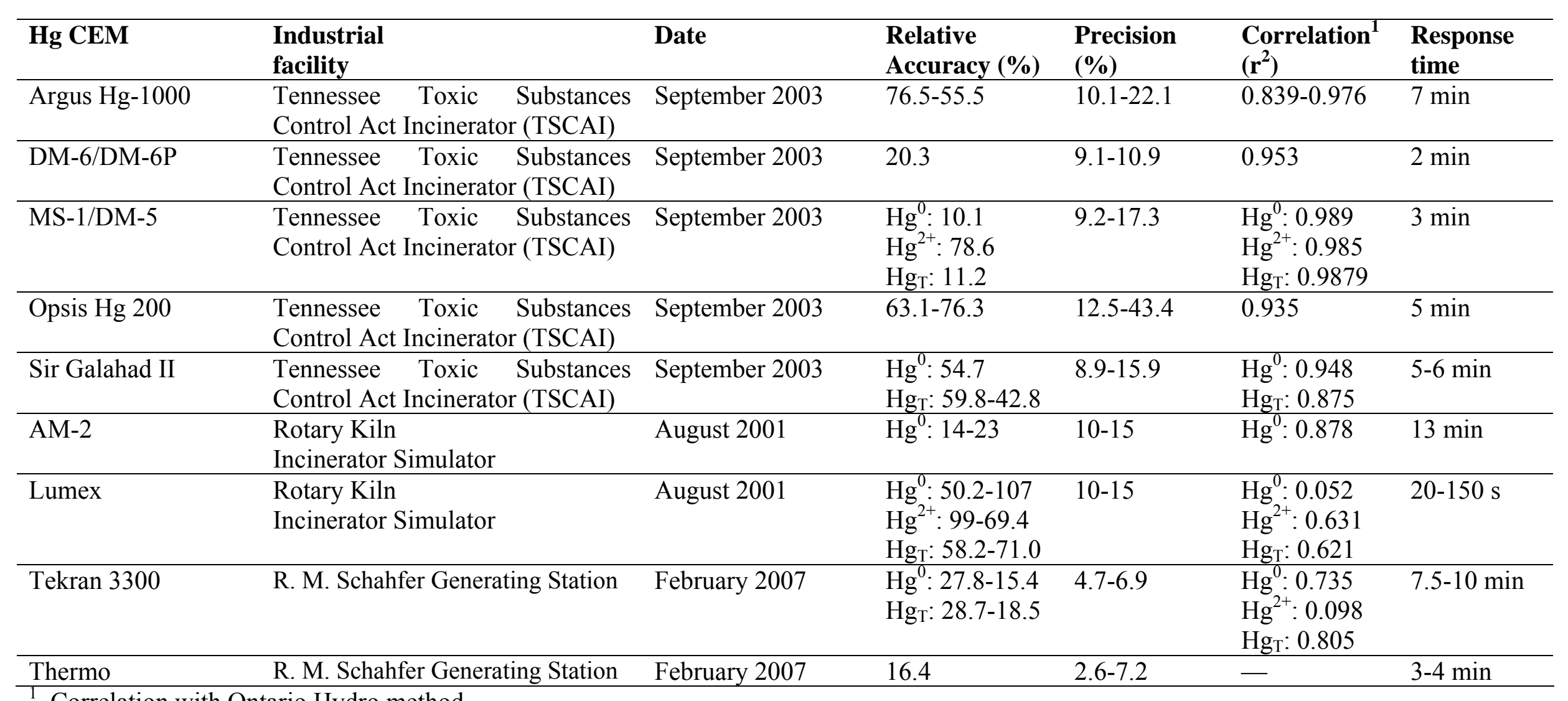

\footnotetext{
${ }^{1}$. Correlation with Ontario Hydro method
} 
Table 4. Precision of the test methods according to ASTM D 6722-01, ASTM D6414-01 and ASTM D6784-02 norms for determining mercury in solids, liquids, particulate matter (PM), water and gases in two pulverized coal combustion (PCC) plants with and without flue gas desulphurization units (FGD).

\begin{tabular}{|c|c|c|c|c|c|c|c|c|c|c|c|c|c|c|}
\hline & \multirow{2}{*}{\multicolumn{2}{|c|}{$\begin{array}{c}\text { In } \\
\text { Coal }\end{array}$}} & \multicolumn{12}{|c|}{ Out } \\
\hline & & & \multicolumn{2}{|c|}{ Bottom ash } & \multicolumn{2}{|c|}{ Fly ash } & \multicolumn{2}{|c|}{ Gypsum } & \multicolumn{2}{|l|}{ PM } & \multicolumn{2}{|c|}{ Gas } & \multicolumn{2}{|c|}{ Water } \\
\hline & $\mu \mathrm{g} \mathrm{g}^{-1}$ & $\%$ & $\mu \mathrm{g} \mathrm{g}^{-1}$ & $\%$ & $\mu \mathrm{g} \mathrm{g}^{-1}$ & $\%$ & $\mu \mathrm{g} \mathrm{g}^{-1}$ & $\%$ & $\mu \mathrm{g} \mathrm{m}^{-3}$ & $\%$ & $\mu \mathrm{g} \mathrm{m} \mathrm{m}^{-3}$ & $\%$ & $\mu \mathrm{g} \mathrm{ml}^{-1}$ & $\%$ \\
\hline PCC & $0.06 \pm 0.02$ & 100 & $0.017 \pm 0.009$ & 0.31 & $0.24 \pm 0.04$ & 39.5 & --- & --- & $0.03 \pm 0.02$ & 0.47 & $3.3 \pm 0.4$ & 59.7 & --- & --- \\
\hline PCC-FGD & $0.09 \pm 0.02$ & 100 & --- & --- & $0.05 \pm 0.02$ & 14.8 & $0.12 \pm 0.03$ & 50.7 & --- & --- & $2.1 \pm 0.8$ & 25.4 & $0.04 \pm 0.02$ & 8.4 \\
\hline
\end{tabular}


